\title{
A Review On The Needs Analysis On Online Learning In Islamic Studies
}

\author{
Nurhafiza Hamzah, Zainatul Nadra Zainol, Hussain Othman
}

\begin{abstract}
Talaqqi is the method developed from Rasulullah saw and his companions in teaching and learning Islam. It applied from that period until now. Hence, the revolution also occurs in Islamic teaching and learning when Muslim seek knowledge through online learning. The purpose of this study is to identify the growing needs of online talaqqi development and to gain special attention in Malaysia. The study is qualitative by conducting an in-depth interview on the needs for learning Islamic knowledge online. The data were analyzed using thematic by looking at the tendency to this concept. This study benefited from further study in the field of Islamic education online by impacting the target of more da'wah targets without the boundaries of time and place.
\end{abstract}

Keywords: alaqqi, Islamic online learning.

\section{INTRODUCTION}

Islamic education system in Malaysia has various developmental and development stages. Through the Fourth Industrial Revolution, the development of religious learning must also be accompanied by the modernization and technological manipulation of mutual benefits. The society continues to be presented with the multiple options to determine the direction of learning required to meet the needs of human capital. Through the public's awareness of religious knowledge, this has led to the development of Islamic studies to keep track of the challenges and religious issues today.

This study is aimed at general review by identifying the growing needs of online talaqqi development particularly in Malaysia. The discussion of this study focuses on the importance of learning according to Islam. In addition, preliminary surveys also found the need for learning Islamic knowledge online based on a number of issues arising and related discussions were also explained.

\section{LITERATURE REVIEW}

Islam is a complete religion as a way of life. All deeds and practices depend on the teachings and principles taught through the teaching of the Quran and the Sunnah. The demand of teaching and learning are the duty of every Muslim to ensure that humans are always on the right path.

Allah SWT confirms the privilege of knowledgeable people in the Qur'an to show that knowledgeable people are given the advantage of witnessing the Laa Ilaaha Illallah words other than Allah Himself and the Angels.

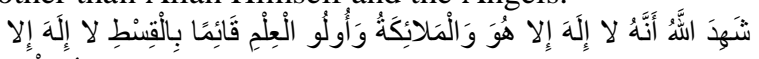

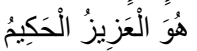

Meaning: "Allah witnesses that there is no deity except Him, and [so do] the angels and those of knowledge [that He is] maintaining [creation] in justice. There is no deity except Him, the Exalted in Might, the Wise."

(Surah Ali Imran: 18)

There are four distinctive privileges of being intellectuals mentioned in the nas above. First, Allah SWT made them the witness of the ultimate sentence which causes the creation of heaven and hell, to decide the prophets and books and the creation of humans and jinn. The second privilege is that God tills the name of the intellectuals with the Lord of the universe and the noble creatures of the angels. In the third privilege, Allah prefers the knowledgeable human of the other human beings in the testimony of the word. While the fourth privilege, the expert is noble and privileged because the testimonies of the noble and privileged sentences are not taken except from noble and special people.

Talaqqi learning methods are also used in the study of hadith knowledge as well as learning the Quran knowledge. The learning from teacher-student meetings that have been practiced since the time of decline of revelation until now continue to preserve the continuity and authenticity of Islamic knowledge. This method ensures that the knowledge derived from a teacher to a pupil is delivered correctly and accepted by the student.

\section{METHODOLOGY/MATERIALS}

This qualitative study carried out an interview data collection method on the selected informants representing the administrative and lecturer groups in the field of Islamic Studies Universiti Tun Hussein Onn Malaysia (UTHM). The data collection procedures conducted during the interview session with 5 informants are as follows:

Revised Manuscript Received on April 19, 2019.

Nurhafiza Hamzah, Student, Universiti Tun Hussein Onn Malaysia, Malaysia.

Zainatul Nadra Zainol, Department of Islamic Studies, Universiti Tun Hussein Onn Malaysia, Malaysia.

Hussain Othman, Associate Professor, Universiti Tun Hussein Onn Malaysia, Malaysia. 
International Conference on Recents Advancements in Engineering and Technology (ICRAET-18) |15th and 16th March 2019|Siddhartha Institute of Technology \& Sciences, Telangana, India.

Table 1: List of interview of the informants

\begin{tabular}{|c|c|c|c|c|c|}
\hline $\begin{array}{l}\mathbf{N} \\
\mathbf{u} \\
\mathbf{m}\end{array}$ & $\begin{array}{c}\text { Nam } \\
\text { e }\end{array}$ & Date & $\begin{array}{l}\text { Ti } \\
\text { me }\end{array}$ & Place & Expertise \\
\hline 1. & $\begin{array}{c}\text { Expe } \\
\text { rt A }\end{array}$ & $\begin{array}{c}2 \\
\text { April } \\
2018\end{array}$ & $\begin{array}{l}2.30 \\
\mathrm{pm}\end{array}$ & $\begin{array}{l}\text { Islamic } \\
\text { Center }\end{array}$ & $\begin{array}{l}\text { Experienc } \\
\text { e in } \\
\text { Islamic } \\
\text { administr } \\
\text { ation }\end{array}$ \\
\hline 2. & $\begin{array}{l}\text { Expe } \\
\text { rt B }\end{array}$ & $\begin{array}{c}3 \\
\text { April } \\
2018\end{array}$ & $\begin{array}{c}3.30 \\
\mathrm{pm}\end{array}$ & $\begin{array}{l}\text { Islamic } \\
\text { Center }\end{array}$ & $\begin{array}{l}\text { Experienc } \\
\text { e in } \\
\text { Islamic } \\
\text { administr } \\
\text { ation }\end{array}$ \\
\hline 3. & $\begin{array}{c}\text { Expe } \\
\text { rt C }\end{array}$ & $\begin{array}{c}3 \\
\text { April } \\
2018\end{array}$ & $\begin{array}{c}11 \\
\text { am }\end{array}$ & $\begin{array}{l}\text { Islamic } \\
\text { Center }\end{array}$ & $\begin{array}{c}\text { Experienc } \\
\text { e in } \\
\text { administr } \\
\text { ation and } \\
\text { online } \\
\text { learning }\end{array}$ \\
\hline 4. & $\begin{array}{l}\text { Expe } \\
\text { rt D }\end{array}$ & $\begin{array}{c}3 \\
\text { April } \\
2018\end{array}$ & $\begin{array}{c}11.3 \\
0 \\
\mathrm{am}\end{array}$ & $\begin{array}{c}\text { Institute } \\
\text { Ahli } \\
\text { Sunnah } \\
\text { Wal } \\
\text { Jamaah }\end{array}$ & $\begin{array}{c}\text { Experienc } \\
\text { e in } \\
\text { Talaqqi } \\
\text { learning }\end{array}$ \\
\hline 5. & $\begin{array}{c}\text { Expe } \\
\text { rt E }\end{array}$ & $\begin{array}{c}3 \\
\text { April } \\
2018\end{array}$ & $\begin{array}{l}2.30 \\
\mathrm{pm}\end{array}$ & $\begin{array}{c}\text { Center of } \\
\text { Languange } \\
\text { Studies }\end{array}$ & $\begin{array}{c}\text { Experienc } \\
\text { e in } \\
\text { online } \\
\text { learning }\end{array}$ \\
\hline
\end{tabular}

The informants are individuals who are directly involved with talaqqi learning and online learning methods. While the main criteria of informal selection are the administrators and lecturers who are directly involved in the administration of da'wah and the learning of Islamic studies.

\section{RESULTS AND FINDINGS}

Online learning is the current way and gaining attention in the education world. This method is not new to the developed nation, but for Malaysia, this method is increasingly gaining the attention of all parties. Even the tendency of students to use technology in everyday learning makes online learning demand increasingly in place.

In the context of learning theory, there are theories related to current learning trends which is e-learning theory. In this theory, it is stated that the students enjoy their learning better when the learning is conducted collaboratively, interactively and privately because the electronic media provides a learning environment based on the principle at anytime and anywhere by anyone (Talesra et al 2003, Karoulis et al , 2004).

In addition, the concept of online learning is closely related to the theory of andragogy that adults learn with selfmotivation according to personal suitability (Knowles et al., 2005; Mazanah, 2001; Merriam \& Caffarella, 1999). This study explains that the working memory theory stated that learning through multimedia can cause the brain to function directly into two types of information namely audio stimulation and visual stimulation. Accordingly, psychological studies proved that verbal information will be more memorable if accompanied by visual images. With multimedia learning, students are more likely to transfer their learning through their cognitive (Cognitive Theory of Multimedia Learning) (Zahiah Binti Kassim, 2010)

\section{A. Analysis of Religious Learning Issue and Alternative} Learning Based on Online Learning

Based on interviews with these respondents, there were problems and issues arising out of informal personal experience and knowledge. Among these are i) poor multilingual mastering of the preachers, ii) dubious authoritative authorization from the point of commissioning and sanad graduation, iii) the confusion of so many teachers caused the investigation to be carried out by the administration before the preaching and dissemination of the speakers, iv) the general public is difficult to make the selection of Islamic references because of too much and no clear source of records and v) dropout following the lectures and syllabus that is set cause the lectures are getting less response.

Table 2: Issues of Religious Learning

\begin{tabular}{|c|c|c|}
\hline Issue 1 & $\begin{array}{l}\text { Poor multilingual mastering of the } \\
\text { preachers }\end{array}$ & \\
\hline Issue 2 & $\begin{array}{l}\text { Dubious authoritative } \\
\text { authorization from the point of } \\
\text { commissioning and sanad } \\
\text { graduation }\end{array}$ & \\
\hline Issue 3 & $\begin{array}{l}\text { The confusion of so many teachers } \\
\text { caused the investigation to be } \\
\text { carried out by the administration } \\
\text { before the preaching and } \\
\text { dissemination of the speakers }\end{array}$ & $\begin{array}{l}\text { 1. Resource } \\
\text { 2. Authority }\end{array}$ \\
\hline Issue 4 & $\begin{array}{l}\text { The general public is difficult to } \\
\text { make the selection of Islamic } \\
\text { references because of too much } \\
\text { and no clear source of records }\end{array}$ & \\
\hline Issue 5 & $\begin{array}{l}\text { Dropout following the lectures } \\
\text { and syllabus that is set cause the } \\
\text { lectures are getting less response. }\end{array}$ & \\
\hline
\end{tabular}

All issues arising need to be addressed by the responsible party because there are some urgent requirements for creating a method and form of online study. The development of the modern education world today requires a special alternative to the needs of the people who need an appropriate and co-opted religious platform.

In previous studies by Zoraini Wati, 2008; Rozinah 2007; Rosenberg 2001; Talesra et al. 2003, Smith and Ragan 1993, showed that learning evolution facilitates adults to continue the lifelong learning process. Long distance self-study and cross border education learning are more relevant, flexible and give students the freedom to start learning at any time based on their personal needs as well as their commitment to their family, work and social life.

Meanwhile, self-determination learning is also known as heutagogy. This method is closely related to learning using the latest technology in the process of acquiring knowledge. The concept used is the determination of the syllabus and the type of field the student wants to learn is determined solely by the student. This method is suitable for use by teachers to $\mathrm{Z}$ and alpha student generation (Ismail, 2018). 
At the same time, one of the principles of adult learning theory is that the role of tutors only helps students to be selfreliant and have self-direction to be responsible for their own learning experiences.

In addition, self-conceptual and autonomous learning concepts do not mean that individuals learn separately from tutors and other students. Instead it is a learning concept that empowers individuals to be responsible for their own learning and at the same time actively involved with tutors and other students.

From the socio-emotional aspect, online learning not only changes the role of teachers, but is very beneficial to the silent and shy students. A quiet and shy person may not have the opportunity to give opinions in the traditional classroom, but they can actively participate in virtual discussion forums, especially in e-group forums.

Responsibility to educators is to provide cyberspace to ensure the transformation of learning experience from the real environment to virtual learning environment.

This clearly demonstrates the need for online religious learning based on the relevant issues. The current generation trends in the use of technology in everyday life can open the opportunity of online learning of Islamic studies.

\section{B. The Needs of Learning Islamic Studies Online}

The learning of Islamic studies online is an alternative to those who love learning with their own space and time. Among the needs in implementing e-learning related to religion are as follows; First, Islamic learning methods that use the main and valid sources and channels. Secondly, the authority of the teacher who conveys the true knowledge and did not go against of the Sunnah Wa Jamaah.

The Islamic community highlights the value of the religious information that causes the information itself to be in the most intense place as enshrined in the Qur'an through surah al-Hujuraat, verse 6 .

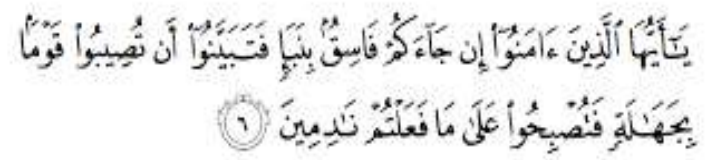

Meaning: "O you who have believed, if there comes to you a disobedient one with information, investigate, lest you harm a people out of ignorance and become, over what you have done, regretful.“

The delivery of news in Islam has been essentially made and delivered from one generation to the next generation based on the mutawatir revealed mutatis (Musthafa al-Siba "e, 1993). In the direction of da'wah, the content of religious information through the internet is seen as too open and free without filtering and can be done by anyone by freely downloading the news.

Meanwhile, an open and independent internet space can make all the clarification of religion so easily available to cause excessive religious information accumulation that leads to the problem of overflowing information. The problem of overflowing information can create confusion in finding reliable information. According to previous studies, Islamic learning information has also been seen to have undergone this phase where consumers are increasingly being squashed by uncontrolled online religious accounts which lead to the occurrence of religious information disruptions that lead to phobic implications on the content of their information.

Therefore, the need for new media as a place of religious learning should be autonomous. Although the Internet is basically a social media that exposes goodness but at the same time blends with various disadvantages in it (Rahmat, 2010). It is difficult for users to separate two intersections that require reasonable decision-making skills. Based on Sharom (2001) stated that this channel has no agreement on good, bad, false, useful, useless because it is all empty, though it can also be versatile, all-powerful, all-purpose.

In addition, the teacher's accreditation can guarantee the credibility of a teacher with the knowledge it possesses. The knowledge of a teacher and the recognition through credentials can give students confidence to gain knowledge with their teachers. For example, most Nusantara scholars have received religious education in Mecca al-Mukarramah delivered by religious teachers who are accredited to control the halaqah of knowledge in the Masjidil- Haram (Hamat, M. F. \& Suhari, M. H., 2012).

From the point of view of education, this opens the widest range of religious learning opportunities for Islamic studies. However, at the same time, it is a challenge for students and teachers in the face of the huge pile of the source reference that is contrary to the grasp of the teachings of Sunnah Wal Jamaah.

\section{CONCLUSION}

Online learning is getting more attention and is being applied by people who are interested in learning online religious knowledge. This makes it easy for them to listen and learn various fields anytime and anywhere. This study is seen as a study that meets current needs to ensure the learning and study of Islamic knowledge continues to be maintained in a new medium to continue to reach the world

It is optional. Appendixes, if needed, appear before the acknowledgment.

\section{ACKNOWLEDGEMENT}

This research was supported by Majlis Agama Islam Negeri Sembilan. We are thankful to our colleagues Dr. Zainatul Nadra Zainol and Prof. Dr. Hussain Othman who provided expertise that greatly assisted the research, appreciation to them for sharing their pearls of wisdom with us during the course of this research

\section{REFERENCES}

1. Hamat, M. F., \& Suhari, M. H. (2012). Pengaruh Pemikiran Akidah al- Ghazāl̄̄ dalam Kitab Jawi : Tinjauan Terhadap Kitab al-Durr al-Nafìs dan Sayr alSālikīn. Jurnal Usuluddin, 36 (Julai-Disember 2012), 2147.

2. Ismail, N. A., \& Wahid, N. A. (2018). Empowering the Self-Efficacy of Teachers in Malaysia through the Academic Revolution 4.0. International Journal of Academic Research in Business and Social Sciences, 8(11), 894-901. 
International Conference on Recents Advancements in Engineering and Technology (ICRAET-18) |15th and 16th March 2019|Siddhartha Institute of Technology \& Sciences, Telangana, India.

3. Karoulis, A. et al. (2004). An expert-based evaluation concerning human factors in ODL Programs: A Preliminary Investigation. Dalam Education Applications: Human Factors and Innovative Approaches. (Claude Ghaoui,editor). UK:Idea Group Inc.

4. Mazanah, M. (2001). Adult and Continuing Education in Malaysia. Kuala Lumpur: Universiti Putra Malaysia.

5. Merriam, S.B. \& Caffarella. R.S. (1999). Learning in Adulthood: A Comprehensive guide. San Francisco: Jossey-Bass Publishers.

6. Mohd Sani Badron. (2009). Zaman Ledakan Teknologi Maklumat dan Kemajuan Pengetahuan dalam Kerangka Pandangan Hidup Islam. Jurnal Akidah dan Pemikiran Islam (AFKAR). 1: 83-108.

7. Musthafa al-Siba"e. (1993). The Biography Seerah of Allah"s Prophet. Ghassan Abdel Fattah. Dar Makkah: Carlo Shariffa.

8. Rahmat Ghazali. (2010). Cabaran Daripada Kewartawanan Internet. Pemikir. Kuala Lumpur: Utusan Publications \& Distributor Sdn Bhd.

9. Sharom TM Sulaiman. (2001). Budaya Hiper dan Ekstasi Gaya Hidup Remaja Alam Siber. Jurnal Yadim. 2: 1-12.

10. Zoraini Wati Abas. (2008). Globalisation of education through open distance learning. Dlm Sarjit Kaur, Morshidi Sirat \& Norzaini Azman (pnyt.). Globalisation and Internationalisation of Higher Education in Malaysia. Pulau Pinang: Penerbit Universiti Sains Malaysia.

\section{AUTHORS PROFILE}

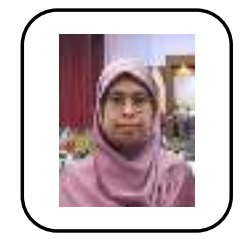

First Author The author is a student in the field of Islamic studies at the level of doctoral studies. Her study on Islamic learning online knowledge. Previous studies at the master level are the acceptance of religious e-books among students and lecturers of UTHM. She worked as a publishing officer at a university publisher for 10 years before study leave.

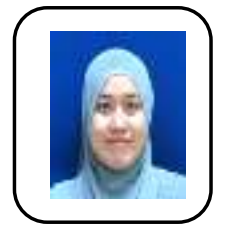

Second Author Nur Zainatul Nadra Zainol currently works at the Department of Islamic Studies, Universiti Tun Hussein Onn Malaysia. Nur Zainatul Nadra does research in Islamic Theology, Interpertation on al-Quran and hermeneutics. Their current project is 'Study on Nasr Hamid Abu Zayd Thought on Justice and Equality'.

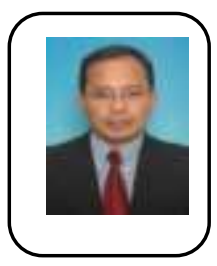

Third Author Associate Professor Dr. Hussain Othman is Past Visiting Scholar at Prince Alwaleed bin Talal Centre of Islamic Studies, University of Cambridge, United Kingdom (September 2013 - June 2014). He is affiliated with Universiti Tun Hussein Onn Malaysia. His research interest is in Islamic and Malay cosmological thought, teaching and learning at higher education specifically on Problem-based Learning. 